\title{
Discrediting the Dutch: A French Account of the Year of Disaster for Arab Audiences
}

\author{
Rosanne BAARs And Josephine VAn DEN BENT
}

Rosanne Baars is lecturer in History at the University of Amsterdam. Her most recent book, Rumours of Revolt. Civil War and the Emergence of a Transnational News Culture in France and the Netherlands, 1561-1598, will be published by Brill in May 2021. She has also published on maritime history and Dutch-Ottoman diplomacy. Her research interests include the reception of news and media, diplomatic history, early modern France, and the Ottoman Empire.

Josephine van den Bent is postdoctoral researcher at the history department of Radboud University Nijmegen, investigating water management in Middle Eastern cities (c. 700-1500) as part of the Nwo-funded project 'Source of Life'. Her PhD thesis (University of Amsterdam, 2020) analysed the representation of the Mongols in the Mamluk sultanate of Egypt and Syria, c. 1250-1350. Her research interests include ethnic stereotyping, urban organisation, and the medieval and early modern Middle East. She is also editor-in-chief of the semi-academic journal ZemZem. Tijdschrift over het Midden-Oosten, Noord-Afrika en islam.

\begin{abstract}
Recent historiography has demonstrated how Istanbul became part of a European media landscape in the seventeenth century. This article argues that European countries not only targeted the Ottoman Porte but also tried to reach Arabic-speaking audiences in other major Ottoman cities, such as Aleppo. It does so through an analysis of a remarkable source, an Arabic manuscript pamphlet written by a Frenchman in Aleppo in January 1673, which tells the story of the exploits of Louis XIV in the Dutch Republic during the Year of Disaster. The article will demonstrate the ways in which the French author attempted to discredit the Dutch in the eyes of the inhabitants of Aleppo. An attached Arabic translation of a Neolatin political fable in verse
\end{abstract}

DOI 10.18352/emlc.145 - URL: http://www.emlc-journal.org

Publisher: Stichting EMLC, supported by Utrecht University Library Open Access Journals | The Netherlands Copyright: The Author(s). This work is licensed under a Creative Commons Attribution-NonCommercial 4.0 International License. 
shows the way by which the author imported a European discourse and a European way of influencing audiences to seventeenth-century Syria. The French saw benefits in expanding their 'image battle' into the Ottoman Empire and made a conscious attempt to make their propaganda as effective as possible. By studying this pamphlet, we can also further our understanding of the way early modern pamphleteers considered their audiences.

Keywords: Year of Disaster (1672), Louis xiv, Ottoman Empire, Aleppo, public diplomacy, pamphleteering 


\title{
Discrediting the Dutch: A French Account of the Year of Disaster for Arab Audiences
}

\author{
Rosanne BAARs And Josephine VAn DEN BENT
}

On 14 December 1673, an article in the bi-weekly newspaper from The Hague, the Haegse Post-tydinghe, reported the latest news from Paris. A Mr. De Croix, secretary of the French ambassador at the Ottoman Court, Marquis de Nointel, brought letters confirming the new alliance between Louis XIV and the Ottoman Porte. These new capitulations stipulated favourable political and trade privileges for France. According to secretary De Croix, the successful negotiation of these new and advantageous treaties was due to the conquests of Louis XIV in the Dutch Republic the year before, 'of which the rumour had spread very favourably at the court of the Great Turk'. ${ }^{1}$ The writer of the Dutch newspaper reacted derisively:

These perceptions are not very hopeful, when the tidings of the hasty and cowardly retreat from this great Conquest will reach the ears [of the Porte], because when the first tidings have caused this realm a good reputation, the second cannot but cause the opposite effect, and produce the deepest contempt for the entire Nation. ${ }^{2}$

Through a remarkable source, we are able to reconstruct the tale the French had spread of their Dutch conquest in 1672 throughout the Ottoman Empire. The Bibliothèque nationale de France in Paris owns a manuscript pamphlet, written by a Frenchman in Arabic in January 1673, that tells the story of the exploits of Louis XIV in the Dutch Republic. The author, François Pétis de la Croix, explicitly targets the inhabitants of Aleppo and other cities in Syria. The pamphlet, consisting of twenty-six pages in Arabic, meticulously recounts the story of the battles and sieges in the Dutch Republic, enumerating all the conquered cities and the deeds of Louis's most important generals until 22 October 1672, the date of the last letters sent from Paris to the Ottoman Empire. This pamphlet was, in its own words, 'distributed in Aleppo in Syria and in other known important towns in the

1 Haegse Donderdaegse Post-tydinghe, 14 December 1673 (The Hague: Chrispinus Hoeckwater), 'Vranckryck'. We are grateful to Nina van Kampen, Richard van Leeuwen, David van der Linden, and Ghazwan Yaghi for their assistance in researching this article.

2 Haegse Donderdaegse Post-tydinghe, 14 December 1673: 'Maar weynigh ister aen d'observantien te hopen, wanneer de tydinghe van de schielijcke en blode verlatinge van alle dese groote Conqueste sal ter hooren komen, want indien het eerste eenige reputatie voor de Wapenen van dit Rijk heeft toegebracht, 't tweede kan niet anders voorbrengen als effect contrarie, en aldaer veroorsaecken de grootste verachtinge voor alle de Natie.' 
Ottoman Empire'. The cover of the accompanying French translation of the pamphlet provides the context in which this pamphlet was distributed: it was to contradict and counter 'writings of the Dutch that they had spread earlier in the Ottoman Empire', which had impugned the honour of Louis XIV. ${ }^{3}$

Recent historiography has demonstrated the 'connectedness' between the Ottoman Empire and Europe, stressing how Istanbul became part of a European media landscape in the seventeenth century. ${ }^{4}$ Nevertheless, most scholars have focused on the European diplomats, Levantines, and Ottoman Christian audiences who participated in the European media exchange. They have mostly considered diplomatic correspondences, the arrival of Western newsletters in the Ottoman Empire, and the correspondences of Christian missions. ${ }^{5}$ Moreover, news from the Ottoman Empire in Europe has always been better researched than vice versa. As John-Paul Ghobrial has noted, 'if events in Istanbul proved a regular subject in scribal and printed media circulating in Europe, less attention has been given to how news from Europe circulated in the Ottoman world'. ${ }^{6}$

This article argues that in the seventeenth century, European countries did not only integrate the Ottoman Empire in their European news networks, but also endeavoured to involve Ottoman audiences in contemporary European pamphlet wars. They not only targeted the Ottoman Porte and its entourage but also tried to reach Arabicspeaking audiences in other major Ottoman cities. Much has been written about the role of media during the Year of Disaster, which spurred an unprecedented number of pamphlets in the Dutch Republic. ${ }^{7}$ The subject of the image-building and glorification of Louis XIV has been another major theme in historiography. ${ }^{8}$ Helmer Helmers has underlined the importance of public diplomacy in the early modern age, in which 'the traditional way to engage with foreign audiences was through pamphlets'. ${ }^{9}$ As we will show here, European diplomats did not limit their propaganda to Europe, but used the same tried and tested methods of spreading pamphlets to influence the Ottoman public. However, due to the absence of Ottoman printing presses, this must have been

3 Paris, Bibliothèque nationale de France (hereafter BnF), Ms Arabe 1907, Jean François La Croix, Relation des victoires de Louis XIV sur les Hollandais, en arabe, suivie de la fable du Soleil et des grenouilles, 1672 [1673]; Paris, BnF, ms Arabe 1908, Jean François La Croix, fils de l'interprète Pétis de La Croix, Relation des victoires de Louis XIV sur les Hollandais, en arabe, suivie de la fable du Soleil et des grenouilles, 1673.

4 Ghobrial, Whispers, 7, 94.

5 In the past decade, the stress has been on the Levantine 'go-betweens' who facilitated European-Ottoman trade, diplomacy, and news exchange. See for instance Dursteler, Venetians in Constantinople; Do Paço, 'A Social History'; Rothman, 'Interpreting dragomans'; Rothman, Brokering Empire; Trivellato, 'Renaissance Italy'; De Vivo, 'Microhistories'.

6 Ghobrial, Whispers, 95.

7 Harms, Uitvinding van de publieke opinie, 106. See for recent publications on publicity and media during the Year of Disaster: Brouwer, Levenstekens; Haks, Vaderland, 21-57; Van Nierop, Life of Romeyn de Hooghe, 89-138; Panhuysen, Rampjaar 1672; Reinders, Printed Pandemonium. On the French experience of the Dutch war, see Montoya, 'Zie hier een vreemde oorlog'.

8 Boitel, L'image noire; Burke, Fabrication; Claydon and Levillain (eds.), Louis XIV Outside in; Levillain, Vaincre Louis XIV; Mansel, King of the World.

9 Helmers, 'Public Diplomacy', 406. 
more challenging and time-consuming than in France or the Dutch Republic. ${ }^{10}$ Furthermore, the French author had the demanding task of appealing to an audience with little knowledge of the background of the conflict, and which held different cultural values. $^{11}$

Through a thorough analysis of the Arabic text, and a comparison with the French translation, we will demonstrate the ways in which the French attempted to discredit the Dutch in the eyes of the inhabitants of Aleppo. The pamphlet poses some further questions. Why would the French target the commercial city of Aleppo, situated far away from the centre of Ottoman government? What strategies did the author employ to engage Arab audiences to a distant conflict? What were the themes that the pamphlet addressed? In answering these questions, we will show that media concerning the Year of Disaster travelled beyond the borders of Western Europe. It shows that European rulers and diplomats were concerned with their image not only in the Ottoman court, but also beyond that in the wider empire. Moreover, studying this pamphlet can enrich our understanding of the way early modern pamphleteers considered their audience.

\section{Franco-Dutch Rivalry in the Levant in the Seventeenth Century}

In the 1670 s, the French launched a diplomatic campaign in the Ottoman Empire to stimulate their own Levant trade and undermine the commercial activities of the Dutch. Since the beginning of the seventeenth century, the Dutch commercial presence in the Ottoman Empire had been growing, while at the same time Dutch diplomatic delegations negotiated with the Ottoman Porte for favourable tariffs and trade privileges. The 1640 s saw the most prominent rise of the Dutch Levant Trade. ${ }^{12}$ Dutch merchant houses in Aleppo focused on silk and mohair yarns from western and central Anatolia. ${ }^{13}$ Over the course of the seventeenth century, the Dutch focus shifted to the city of Izmir (Smyrna), which developed into an important commercial centre for Dutch trade. The bi-yearly Dutch armed convoy of 'great ships' from Izmir in June and November developed stability in its Levant trade. Anglo-Dutch and Anglo-French rivalries in the Levant have received considerably more attention in historiography than Franco-Dutch competition. ${ }^{14}$ Yet in the 1670s, the French chose to attack the Dutch rather than the English. By 1672, only two Dutch merchant houses remained in Aleppo - both, rather ironically, under protection of the French consul. ${ }^{15}$ There was clearly tension between the interests of European powers in

10 Haddad, 'People before Print'.

11 For the challenges of early modern Eurasian diplomacy, see Amsler, Harrison, and Windler, 'Eurasian Diplomacies'.

12 Israel, 'Trade', 14.

13 Israel, 'Trade', 16-17. See also Olnon, “"A most agreeable and pleasant creature”?'.

14 Zwierlein, French and British; Hamilton, De Groot, and Van den Boogert (eds.), Friends and Rivals; Levillain, Angleterre, Hollande, France.

15 Van den Boogert, 'European patronage', 195-197; Israel, 'Trade', 18; Israel, 'The Dutch Merchant Colonies', 101. On a Dutch traveller's account to the Ottoman Empire in these years, see Oddens, Vorstelijk Voorland. 
Western Europe and the interests of their merchant nations within the Ottoman Empire, and the local situation was often accorded more importance than that at home, leading to compromises between nominally rival groups.

Aleppo was an Arabic-speaking city with a Muslim majority. The Ottoman rulers had favoured the city's development into an international trading hub, and it became Syria's most important entrepôt. ${ }^{16}$ The city was home to a large number of different ethnic and religious communities, including (but not limited to) Turkish-speaking Ottoman officials, local Arabic-speaking Muslims, Christians, and Jews, as well as various European trading nations, such as the Venetians, English, French, and Dutch. ${ }^{17}$ The year 1574 saw the construction of the Khan al-Gumruk, a customs inn, which also functioned as the residence of the French, Dutch, and English consuls. ${ }^{18}$ The city was run by an Ottoman administration, but there was also a local, civilian elite. This included the cultural elite of the 'ulamä' (the Muslim scholars), but also the social and economic higher echelons - some of whom further buttressed their status by claiming descent from the prophet, which entailed social status but also had economic benefits. Many merchants belonged to this group, and these $a s h r a \bar{f}$ in general looked after the interests of the Arabic-speaking, Sunni Muslim urban elite. ${ }^{19}$ Local Christians were also regularly engaged in trade. ${ }^{20}$

The Arabic pamphlet was clearly directed at an Arabic-speaking urban elite, rather than at Turkish-speaking Ottoman officials: while the latter may have been able to read it, a text produced primarily for their benefit would have been composed in Turkish. With its international character, the city of Aleppo had an elite and middleclass readership that might well have been interested in a pamphlet like this one, although it remains hard to pinpoint who, exactly, the (envisioned) readers of this text were. The work of Nir Shafir on the 'reading circles of Damascus's artisans and merchants' nonetheless provides a useful point of comparison. ${ }^{21}$ This reading culture may well have been reminiscent of that of Aleppo and 'other known important towns in the Ottoman Empire', in which the pamphlet was by its own account distributed. Investigating reading and pamphleteering in this period, Shafir describes a pamphlet culture in which cheap manuscripts, often topical, were exchanged between acquaintances across the Ottoman Empire. ${ }^{22}$ The French pamphlet thus appeared in an existing pamphlet culture and its author likely expected a similar audience for his text.

The pamphlet was far from the only way in which the French engaged with a local audience. In their rivalry with other European powers, including the Dutch, the French were actively displaying their power. One place in which they did so was the Aleppo consulate: the Khan al-Gumruk's salle consulaire was adorned with tapestries, portraits, and heraldic shields, as well as a leather chair. In 1693 the consul noted: 'You would not believe how

16 Mansel, Aleppo, 7-8; Masters, The Origins, 13-15.

17 Masters, Origins, 14-17, 41-42; Mansel, Aleppo, 7. On early modern Aleppo, see also Watenpaugh, Image; Wilkins, Forging Urban Solidarities.

18 Mansel, Aleppo, 12.

19 Masters, The Origins, 45-47. On some of the tensions between the local ulama and the Ottoman rulership, see for instance Rafeq, 'Social groups', 79-88.

20 Masters, Origins, 63-64.

21 Shafir, Road from Damascus, 109.

22 Shafir, Road from Damascus, 109, 120-124. 
many people in this city come to see the furniture and admire the portraits of our kings. ${ }^{23}$ In addition to realising trade and political contacts, the French were also interested in supporting French Christian missions and in securing the safety of Catholic pilgrims, as well as in maintaining good relations with Arab Christians. When Marquis De Nointel came to Aleppo in 1674, he visited Syriac and Maronite churches. There, the Syriac patriarch delivered a sermon in praise of Louis $\mathrm{XIV}^{24}$ In a letter to Louis's foreign minister Simon Arnauld de Pomponne, De Nointel recounted how he approached to the sound of trumpets and drums, surrounded by my household and followed by more than a hundred horseman who composed the French nation. All the streets were lined with an extraordinary concourse of people, not only Christians, but also Turks [Muslims]. ${ }^{25}$ Their display of power was not without its effects, at least according to De Nointel's report: apparently, the Syriac, Armenian, and Orthodox patriarchs, as well as the leader of the Yezidis, urged a French invasion of the Ottoman Empire. ${ }^{26}$

Louis XIV was not only interested in the Ottoman Empire from a political and strategic standpoint, but also from a cultural perspective. ${ }^{27}$ Scholars and French consuls were sent on cultural expeditions to seek manuscripts owned by religious scholars, often purchasing them when their owners passed away. ${ }^{28}$ In the same period, French capitulations, stemming originally from 1569 , were renewed in June 1673 , much to the advantage of the French. According to Mansel, this was due in part to the positive impression Louis's victories in the Dutch Republic had made on the Ottoman government. ${ }^{29}$ The French diplomatic offensive in the Ottoman Empire continued until the late seventeenth century, and it bore fruit: Dutch power in the Levant was curtailed. As Jonathan Israel has observed: 'What the English had failed to achieve by war - the elimination of the Dutch as major competitors for the Levant trade - the French had achieved by the early eighteenth century through a combination of diplomacy, war, and mercantilist initiatives. '30 The two approaches of political strategy and orientalist scholarship came together in the person of François Pétis de la Croix and his Aleppo pamphlet.

\section{The Aleppo Pamphlet}

The Bibliothèque nationale in Paris possesses two copies of a pamphlet entitled 'Risāla mukhtașara taḥtawī 'alā dhikr al-futūḥāt al-muyassara li-l-malik al-a 'ẓam qayṣarā Faransā',

23 Cited in Mansel, Aleppo, 16.

24 Mansel, Aleppo, 33.

25 Nointel to Pomponne, Athens, 17 December 1674, cited in Mansel, Aleppo, 33. As the 'French nation' included all those under French protection, the procession must have, ironically, included Dutch participants as well.

26 Nointel to Pomponne, Athens, 17 December 1674, cited in Mansel, Aleppo, 33. See also Vandal, Odyssee, 8-9, 156,330 .

27 Mansel, King, 292.

28 Mansel, King, 297.

29 Mansel, King, 292-293.

30 Israel, 'Trade', 23. 


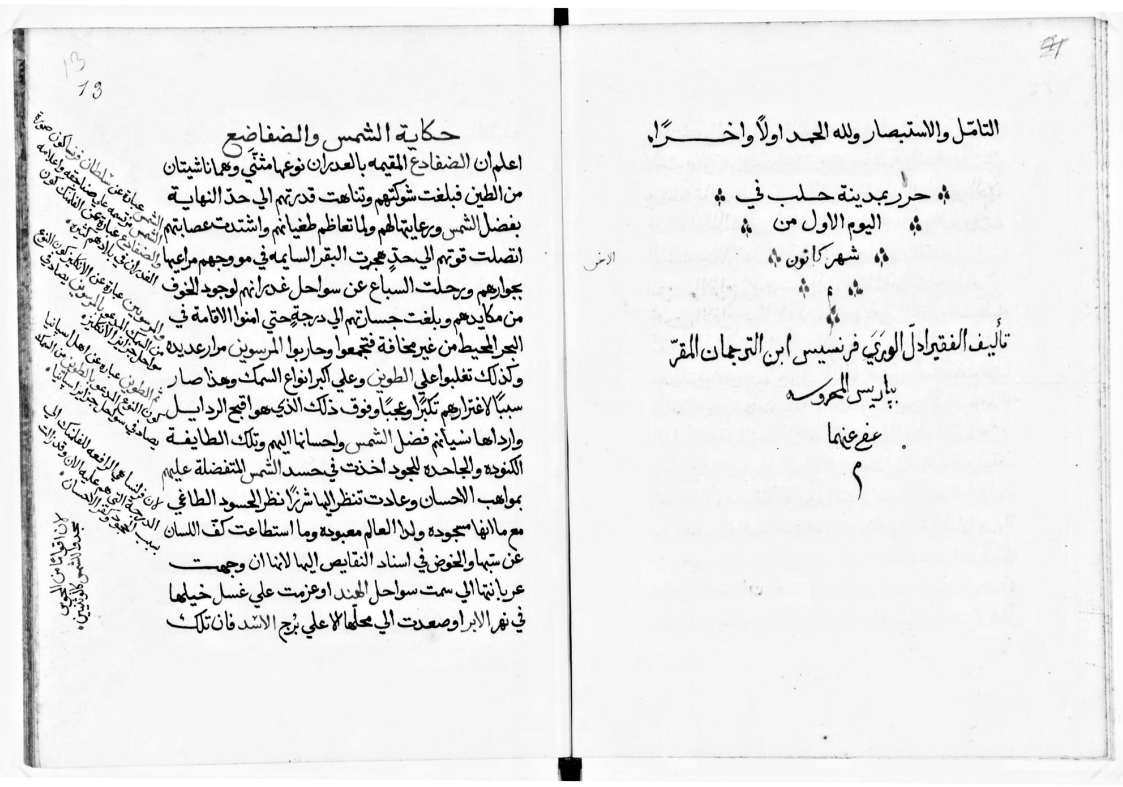

Fig. 1 Jean François La Croix, Relation des victoires de Louis XIV sur les Hollandais, en arabe (1673). Paris, Bibliothèque nationale de France, Ms Arabe 1908, fols. 12v-13r.

or in French, 'Relation en abregé qui marque les conquests du très puissant Empereur de France' (fig. 1). ${ }^{31}$ These two manuscripts, listed as Arabe 1907 and Arabe 1908, both contain the Arabic text of the pamphlet and a French translation. Arabe 1907 consists of twenty-seven folios in which the Arabic and French appear side by side. The Arabic text is neatly written; the French handwriting is slightly more informal, and the first four and a half pages are difficult to read, as the ink is much lighter (diluted, perhaps?). Arabe 1908 consists of fourteen folios in Arabic followed by twenty folios in French - the handwriting in the latter is considerably neater than that in Arabe 1907. ${ }^{32}$

The author is clear about his reasons for writing the pamphlet: news had been going around in the Ottoman Empire about the march of Louis XIV in the Dutch Republic. 'Several persons of quality and friends' had heard about the conquests of the French 'sultan' and the capture of a large number of important Dutch cities in a short time. They

31 The transliteration of Arabic text has been carried out according to the rules of the EI 3 , with some slight modifications. The text has some characteristics of Middle Arabic, such as the use of $y \bar{a}$ ' for hamza in participia (e.g., qāyid instead of $q \bar{a}$ ' id), as well as some orthographic 'deviations' from the classical Arabic norm (such as the use of final $y \bar{a}$ ' for an alif maqșūrā, and the general absence of hamzas). In our transliteration of the Arabic, we have chosen to employ the standard spelling of those words for the sake of clarity. The many French and Dutch names and place names present in the Arabic text are only occasionally provided with vowel markings. When transliterating them we have used the vowels that we think De la Croix intended there and/or that would most likely be inferred by an Arab reader.

32 BnF, ms Arabe 1907 and Ms Arabe 1908. 
had encouraged him to use their information in writing this pamphlet. The author provides the public with an abridged version of the 'heroic deeds' of the leaders of France. ${ }^{33}$

Who is this person who knew to address Aleppo audiences in Arab? The author signed the Arabic section of Arabe 1908 with 'Fransīs, son of the interpreter based in Paris', signing off with 'Jean-François La Croix, son of the interpreter' in the French translation (Arabe 1907 is unsigned). Interestingly, there were two men named De la Croix in the Ottoman Empire at the time, both connected to the French court. The first was the man already mentioned in the first paragraph of this article, Sieur Jean-François de la Croix, who served as secretary to the French ambassador Marquis De Nointel. The second was François Pétis de la Croix, son of François Pétis de la Croix, the Turkish and Arabic translator of Louis XIV at the French court. These two, or even three different De la Croix with Ottoman connections have often caused confusion among historians. ${ }^{34}$ Pétis de la Croix the Younger (b. 1653) had started learning Oriental languages at a young age, and in 1670 Jean-Baptiste Colbert, Louis's minister of State, sent him to Syria to learn more about the Middle East and to collect antiquities. This was part of a programme: the king and Colbert wished to 'decorate our France with the remains of the Orient', according to a letter by Colbert to the Marquis de Nointel on 10 November 1674, and to turn Paris into 'a new Athens'. ${ }^{35}$

Pétis de la Croix the Younger stayed in Aleppo from November 1670 to April 1674, where he trained himself in both literary and vernacular Arabic as well as Turkish, and took an interest in Arabic poetry and music. According to Paul Sebag, he is the author of this pamphlet, which 'enjoyed a great success in different cities throughout the Middle East'. ${ }^{36}$ De la Croix also acquired medals and manuscripts for the collection of Louis XIV. However, as it is highly probable that ambassador Marquis De Nointel was behind the commission of this pamphlet, it is plausible that his secretary Jean-François was involved in supplying the content, leading to a collaboration of both De la Croix. The actual composition of the Arabic text must have been accomplished by Pétis de la Croix the Younger, the orientalist who had been learning Arabic for many years and had been staying in Syria for more than two years. It is interesting to see whom the French diplomats had chosen to address an Arab audience. They did not simply pick someone who knew both languages, but asked a young scholar who also studied other aspects of Arabic literature and culture. He was a 'trans-imperial actor', a man who knew how to navigate between different cultures, and accommodate both. ${ }^{37}$

In 1672 , the Dutch Republic found itself threatened by a coalition of the French, the English, Münster, and Cologne. The opening of hostilities was incidentally connected with the Dutch-Ottoman trade as, on 23 March, a returning Dutch Levant convoy was attacked by English warships close to the Isle of Wight. Shortly afterwards, Louis XIV marched with an army of 118,000 infantry and 12,500 cavalry to the Dutch Republic. They outnumbered

33 BnF, ms Arabe 1907, fol. 3r; BnF, Ms Arabe 1908, fol. 2r.

34 Sebag, 'Sur deux orientalistes', 90.

35 Mansel, King, 297.

36 Sebag, 'Sur deux orientalistes', 91.

37 On trans-imperial subjects see Rothman, Brokering Empire. 
the Dutch army, led by William III of Orange, by four to one. French troops easily conquered fortified towns in the south and east of the Dutch Republic. The defence line built upon the River IJssel could not halt the French army. The Dutch concentrated their efforts on the defence of the provinces of Holland, Zeeland, and Utrecht. While Utrecht surrendered to the French, Holland was saved by its engineers, who took advantage of its aspect to release massive inundations, preventing the advance of the French troops. Meanwhile, internal political tensions culminated in the murder of Grand Pensionary Johan de Witt and his brother Cornelis in August 1672..38

The pamphlet unsurprisingly describes these events from the viewpoint of Louis XIV and his generals. Most of the first section of the text is dedicated to explaining the reasons for Louis's campaign. Two themes are central to the author's argument. First, he underlines the ingratitude of the Dutch, who had received ample help from the French and English in their war against Spain. When they felt powerful, and had become rich, they showed nothing but arrogance and pride to their former allies. As a republic, they made an effort to corrupt the English, hinder their trade and that of France, and detract them from their obedience to the King of England. ${ }^{39}$ The second theme is that of slandering the French king. The Dutch sent envoys to the 'diwans of sultans' everywhere and aroused hostility in the hearts of the 'Frankish kings' - the usual Arabic designation for 'European' against the Emperor (qaysarā) of France. Unable to endure these offences any longer, the French emperor entered into a treaty with the King of England to attack the Dutch and 'eliminate them and make an end to their signs of stupidity and arrogance'. ${ }^{40}$

The slander of the French king among his fellow monarchs seems to have particularly grieved Louis XIV. It is small wonder that a king so involved in the promotion of his image must have felt vindictiveness towards those who tried to corrupt it. The patrons and author of the pamphlet, coming from courtly circles, demonstrate their awareness of just how significant the violation of Louis's glory had been. According to Philip Mansel, Louis's enthusiasm for the Dutch enterprise of 1672 can partly be ascribed to a Dutch insult some years earlier. Louis was fond of collecting medals, and had a medal made to commemorate every special occasion for his medal cabinet. In 1669-1670 Coenraad van Beuningen, a Dutch diplomat and future mayor of Amsterdam, was reported to have planned the minting of a medal of Joshua stopping the sun in the middle of the sky, with the inscription 'Stetit sol in medio coeli'. Van Beuningen denied his complicity but the harm had been done: Louis felt attacked in both his use of the image of Sun King and his passion for collecting medals. In his private memoirs, Louis repeatedly noted the ingratitude, ignorance, and insupportable vanity' of the Dutch Republic, 'cette altière et ingrate nation', and defended for posterity 'my desire to revenge myself for the insult I had received from the Dutch'. ${ }^{41}$

38 Israel, Dutch Republic, 796-797.

39 Compare Helmers, The Royalist Republic.

40 BnF, ms Arabe 1907, fol. 5r; BnF, Ms Arabe 1908, fol. 3r. See also Ziegler, 'Image battles'.

41 There had been another 'medal-gate' in 1668. After mediating the Treaty of Aix-la-Chapelle, the States-General had minted a medal describing the Dutch Republic as the peacemaker and arbitrator of Europe. Louis was offended by this and consequently demanded yearly diplomatic missions from the Dutch, who had to provide him with 'gold medals proclaiming gratitude for French help winning Dutch independence from Spain': Mansel, King of the World, 163-164. 


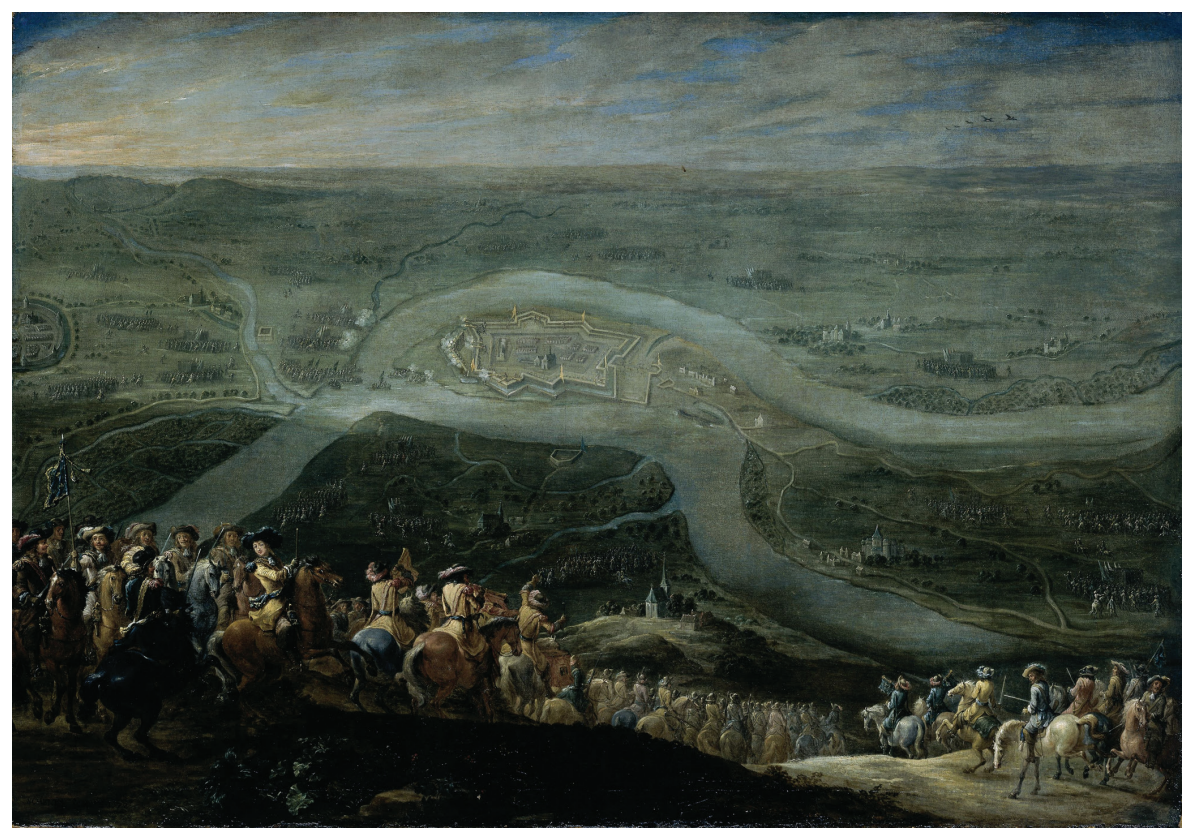

Fig. 2 Lambert de Hondt II, King Louis XIV and his entourage at the Siege of Schenkenschans, c. 1675, oil on canvas, $62 \times 85 \mathrm{~cm}$, Amsterdam, Rijksmuseum.

The Arabic pamphlet also describes the gathering and the mustering of the troops in the Southern Netherlands in May 1672. The French king divided his troops between the Duke of Condé and the Marquis de Chamilly and commanded the largest part of the army, assisted by his brother and the Viscount of Turenne. The pamphlet describes extensively - and with a great amount of detail - how Louis and his commanders besieged cities in the southern and eastern part of the Dutch Republic. Following these sieges, Louis crossed to the heart of the country, surrounded by the rivers IJssel, Waal, and Rhine. After a fierce battle the French crossed the Rhine, one of their major victories. Louis's aim was to confront the Prince of Orange directly, but he had retreated to Utrecht. The French conquered Arnhem and Doesburg, while the troops of the Bishop of Münster seized Deventer, and the brother of the French king conquered Zutphen. ${ }^{42}$

In June, the troops of Louis marched on northwards and conquered Amersfoort and Naarden. Other French troops besieged cities, forts, and castles, including Rhenen, Wageningen, Amerongen, Vianen, Tiel, Elburg, Harderwijk, Kampen, Zwolle, and Ommen. An important victory was the capture of Schenkenschans (fig. 2), which was heretofore a famously impregnable fortress. The city of Utrecht refused to admit the Prince of Orange and his troops, instead surrendering to Louis. Some days afterwards, Louis visited the 
city on foot, where the inhabitants cheered him; De la Croix stressed how the population considered him not as an enemy, but as a loving father. ${ }^{43}$ Turenne conquered Nijmegen, Chamilly took Grave, and the Bishop of Münster seized Coevorden. The frightened Dutch flooded their land and became isolated. On top of these disasters, conflict arose among the Dutch: some desired the Prince of Orange as leader of all the 'Flemings'; others were less keen. In the meantime, the French corresponded with the English, who sent ambassadors to negotiate. A Flemish attempt to reconquer the city of Woerden was thwarted by the Duke of Luxemburg. ${ }^{44}$

This was the last report the author had received from the Dutch Republic. De la Croix summarised how Louis xIV had conquered seventy-two large towns in two and a half months. Moreover, Louis had allowed Dutch Catholics to celebrate their faith in public again, without fear. Previously they had been hiding, because the general faith is that of the 'accursed Calvin'. ${ }^{45}$ The author states that he received the last letter from Paris on 22 October. He hopes that news will soon arrive that the city of Amsterdam will be conquered, which is the largest city in the world, very powerful and rich. ${ }^{46}$ De la Croix concludes by praising God. Then follows the fable of the Sun and the Frogs, in which the arrogance of the Dutch is stressed again.

\section{Targeting Arab audiences}

In his book The Fabrication of Louis XIV, Peter Burke has shown that the view of the French king was widely projected by images, texts, and other media. Louis's entourage played, for instance, on the themes of the sun and the Ancient Roman emperors. Burke has also considered the intended audience of this imagery. Apart from posterity, Louis's image appealed to both domestic and foreign elites. The other courts of Europe and foreign ambassadors were the most important audiences. Burke discusses some panegyrics in Latin for audiences outside of France, pamphlets in German and Italian, and a few texts in English and Dutch, but he does not mention Arab audiences. ${ }^{47}$ Yet it was this audience that De la Croix had in mind: Arabic-speaking inhabitants of Aleppo and other cities of the Ottoman Empire. How did he target an imagined Arab public? This pamphlet represents the export of a European discourse to the Ottoman Empire, in which the author made a

43 Compare Mansel, King of the World, 170-171, who notes that no-one in Utrecht shouted 'Vive le Roi'.

$44 \mathrm{BnF}$, MS Arabe 1907, fols. 13r-23r; BnF, ms Arabe 1908, fols. 6r-11r.

45 Nabil Matar has emphasised this element of the pamphlet. 'The religious difference', he writes, 'between the French Catholics on the one hand and the Dutch Calvinists and Huguenots on the other underpinned the celebration of "the glorious victories of the great king, the qayșar of France". See Matar, 'The Protestant Reformation through Arab Eyes', 803. But although religious difference played an important role in French politics of the time, including with regard to the Ottoman Empire, this pamphlet pays much more attention to the glory of and conquests by Louis XIV and his being maligned by the Dutch. The mention of religious difference does not appear until the very end of the pamphlet, and emphasises Louis's benevolence towards Dutch Catholics and the Catholic Church rather than focusing on Dutch heresy.

$46 \mathrm{BnF}, \mathrm{ms}$ Arabe 1907, fol. 23V; BnF, Ms Arabe 1908, fol. $12 \mathrm{r}$.

47 Burke, Fabrication, 1-2, 164-165. 
deliberate and considered attempt to appeal to his imagined audience so that he could get his message across. It was not simply an Arabic version of a French text. This is clear from both the contents and the style of the pamphlet: De la Croix provides his readers with relevant background information, so that a Syrian audience would better understand his text, and he appealed to them by adhering to Arabic writing traditions as well as the inclusion of cultural elements and literary devices.

De la Croix's consideration for his imagined audience is evident from the very beginning of this text. Although the French themselves referred to the Dutch as les hollandois (the Hollanders), both in general and in the French version of the pamphlet, that term was apparently not current in seventeenth-century Aleppo. De la Croix took this into account. In his introduction to the pamphlet, he acknowledges this 'real' name, rendering it as al-Walāndiz , going on to say that they 'are known as the Flemings' ${ }^{48}$ From there on, the Dutch are consistently referred to as the Flemings, spelled as al-Falamank until midway through the pamphlet, when the spelling changes to al-Fayamank.

De la Croix is well aware that his imagined audience will have little, if any, knowledge of the political structure, topography, and geography of the Low Countries. The text therefore abounds with geographical explanations and descriptions: De la Croix both attempts to paint a vivid picture of the surroundings, so the audience can imagine itself on the scene (and in the case of his elaborate depictions of fortifications, be impressed by French prowess in conquering them), as well as providing geographical information in terms of distances between towns and relations between major cities and their hinterlands, so that a Syrian reader would have a better understanding of the events. ${ }^{49}$

For instance, when describing 'the river known as the Rhine' (al-nahr al-shahì bi-lrayn), he explains that this is 'a large river, similar to the Amu Darya' (huwa nahr 'azim $y u h \bar{a} k \bar{\imath}$ al-jayhūn ) - a reader would now know what to picture..$^{\circ 0}$ Elsewhere, he explains how, between the Rhine, the Waal, and the IJssel, the latter is the easiest to cross, which is why the Dutch had built extensive and impressive fortifications there, 'to the extent that the river bank appears to be one [big] city wall out of connected buildings, such as towers, approximately twenty stages (marhala), and not in one row, but in two or three'. ${ }^{51}$ The image of endless rows of fortifications full of soldiers and cannons, and especially the fact

48 BnF, ms Arabe 1907, fol. 3r; BnF, Ms Arabe 1908, fol. 2r. The Dutch were also called this in Ottoman Turkish, Efrenk-i Filemenk (Flemish Franks): Masters, The Origins, 77.

49 On geographical knowledge of Europe among the Ottomans in the seventeenth century, see for instance Matar, Europe, 200-201. In 1668, the Dutch ambassador had given the Ottoman sultan a Blaeu-Atlas, to the apparent delight of the sultan: Baars, 'Constantinople', 149.

50 BnF, ms Arabe 1907, fol. 5v; BnF, Ms Arabe 1908, fol. 3v. The Amu Darya, or Oxus river is known in Arabic as Jayhūn. The French translation, interestingly, uses the cognate term Gihon, which designates the Biblical river (Gen. 2:13), rather than 'Oxus'. Nonetheless, it is clear the De la Croix intends to refer to a worldly river here although given its proximity to Aleppo, the Euphrates would perhaps have been a more obvious choice than the rather distant Amu Darya.

$51 \mathrm{BnF}, \mathrm{ms}$ Arabe 1907, fol. 11r; BnF, Ms Arabe 1908, fol. 5v. The marhala is the distance a traveller can cover in a day and is thus a rather variable distance, but twenty such stages (of perhaps some forty-fifty kilometres each) appears to be quite the exaggeration. Perhaps that is why this specific bit of information was left out of the French translation. 
that the French were victorious nonetheless, was clearly supposed to engage and impress the reader.

The author does not go into much detail about the political structure of the Dutch Republic, but he does briefly refer to it when describing how important France's protection has been for the young country, 'their provinces having united and separated themselves, becoming by itself a special kingdom for them [the Dutch]' (ittahadat nawāhinim wa-infașalat wa-' ādat 'alā infirādihā mamlakatan lahum khāșsatan). ${ }^{52}$ Information on the Prince of Orange is equally brief. He is named simply as that, amī Üranjiyā, 'leader of the Flemings' ( $q \bar{a}^{\prime}$ id al-Falamank), midway through the pamphlet, but his person does not receive any real attention. ${ }^{53}$

In his provision of topographical information, however, De la Croix is detailed and careful. Cities and provinces are not only meticulously transliterated, but also briefly introduced and contextualised. To name just a few examples: Emmerich (Amarik) is described as 'one of the biggest cities held by the Flemings'; 54 Deventer (Dawantir) lies on 'the aforementioned river [IJssel], and is a large city in the province called Overijssel (Waraysal)';55 and Utrecht (Ut trik) 'is the largest city in the eponymous province'. ${ }^{56}$ Cities and fortresses are described in relation to one another, and this information could also be impressively detailed. Not only is Naarden reported to be located 'about three miles (amyāl) from the city of Amsterdam', in Arabe 1907 someone - likely De la Croix himself actually amended this, crossing out amyāl and replacing it with farāsikh (parasangs). ${ }^{57}$ Three parasangs equal approximately eighteen kilometres, while three miles would amount to about six kilometres. ${ }^{58}$ The two cities are, in the present day, about twenty kilometres apart, so the change was in fact a correction. De la Croix, well aware that his audience had no familiarity with the area, thus provided ample information on the Dutch topographical context. At times one wonders if the level of detail was really required for a Syrian audience to understand the narrative and to appreciate that he was well informed - besides the details regarding Naarden, De la Croix's very careful vocalisation of the small town of Olst (Ülst) comes to mind, supplying the word with a dhamma and two sukūns, making sure that it would not be mispronounced as, for instance, 'Walasit'. ${ }^{99}$ De la Croix thus helps his imagined audience visualise and understand the contents of his narrative, while at the same time underlining his knowledgeability and thereby his trustworthiness.

Furthermore, De la Croix's training in Arabic language and culture is quite apparent from his text, in which he clearly aims to adhere to various cultural and literary norms. For one, he largely follows the conventions of Arabic texts. He opens the pamphlet with the basmala: bi-sm Allāh al-rahmān al-rahìm, 'in the name of God, the Merciful, the

52 BnF, ms Arabe 1907, fol. 3v; BnF, ms Arabe 1908, fol. 2 .

$53 \mathrm{BnF}, \mathrm{Ms}$ Arabe 1907, fol. 11v; BnF, Ms Arabe 1908, fol. 6r.

$54 \mathrm{BnF}$, Ms Arabe 1907, fol. 9r; BnF, Ms Arabe 1908, fol. $5 \mathrm{r}$.

55 BnF, ms Arabe 1907, fol. 13r; BnF, ms Arabe 1908, fol. 6v.

$56 \mathrm{BnF}, \mathrm{Ms}$ Arabe 1907, fol. 13v; BnF, Ms Arabe 1908, fols. 7r-7v.

57 BnF, ms Arabe 1907, fol. 13r. Cf. BnF, ms Arabe 1908, fol. 7 r.

58 See Hinz, 'Islamische Masse', 62-63.

$59 \mathrm{BnF}, \mathrm{ms}$ Arabe 1907, fol. 9r; BnF, ms Arabe 1908, fol. 5 r. The dhamma indicates a 'u' (classical Arabic has no phoneme 'o'), a sukūn indicates the lack of vowels (classical Arabic never has three consonants in a row). 
Compassionate'. Every text was supposed to open with that - in its absence, it would be considered defective, cut off from blessing. ${ }^{60}$ It is, as is also usual, immediately followed by the hamdala, the praising of God by saying or writing al-hamdu li-lläh. In what follows, the author continues his praise of God, 'who grants victory over the unbelievers and the deniers', and directs a customary formula of good wishes at 'important prophets and saints' (al-șalāt wa-l-salām 'alā akābir ahl al-nubuwa wa-l-wilāya). Although this section uses various standard phrases, some elements are slightly non-standard. The al-șalāt wa-l-salām formula, for instance, was not generally used for saints, and one would normally expect the Islamic prophet Muhammad to be mentioned - as a European Christian, De la Croix might have felt uncomfortable doing so. ${ }^{61}$ Yet both the pamphlet proper and the fable end with standard phrases in praise of God - wa-lillāh al-hamd awwalan wa-äkhiran ('praise be to God, at the beginning and the end') and bi-'awn Allāh ta'ālā wa-tawfíqihi ('with help from God the Exalted'), respectively. ${ }^{62}$ That De la Croix is trying to adhere to the Arabic traditions is also visible in the way he signed Arabe 1908, using the formula al-faqì adhall al-warā, literally 'the poor, humblest of men', al-faqi $r$ being a standard way for authors to refer to themselves when signing off. ${ }^{63} \mathrm{He}$ also asks God for mercy for both himself and his father, and calls Paris Pārīs al-mahrūsa - the latter being an epithet meaning 'protected', generally used for major cities in the region, particularly Cairo, but also for instance Damascus and Istanbul.

The literary style of the pamphlet also shows how De la Croix wished to cater to an Arab readership. Arabic literature frequently uses two or more (near) synonyms in a row, and so does he (e.g., qad ittadaha wa-lāha, it has become clear and it has emerged'). ${ }^{64} \mathrm{He}$ also uses rhyme, for instance describing a few cities as shadìdatan al-bunyān mushayyadatan al-arkān rafí'atan al-judrān (lit: 'strong of construction, imposing of sides, and high of walls'). ${ }^{65}$ Alternatively, he combines rhyme and synonyms, noting for instance that the rapid French conquests were an $a m r$ ' $a j \bar{i} b$ wa-sha'n gharīb ('a wondrous matter and an extraordinary affair') ${ }^{66}$

In addition, he uses fixed expressions, such as describing a French commander answering with al-sam' wa-l-ța' $a$ ('hearing and obeying'), but also a suffixed invocation following his mention of Calvin: Qalwīn al-la'ìn, khadhalahu Allāh ilā yawm al-dīn ('the accursed Calvin, may God forsake him until Judgement Day'). Incidentally, although later used for the Mongols and other enemies, the origins of these suffixed curses lie in the Crusading period, being first used to denote the Franks. ${ }^{67}$ In addition, he used two Arabic proverbs in

6o Carra de Vaux and Gardet, 'Basmala'; Harvey, 'The Author's Introduction', 15; Rosenthal, The Technique, 10. See also Matar, 'The Protestant Reformation through Arab Eyes', 803.

61 See also Rosenthal, Technique, 13.

62 BnF, ms Arabe 1907, fols. 23v, 27v; BnF, Ms Arabe 1908, fols. 12v, 14r. See also Rosenthal, Technique, 12.

63 The manuscript reads 'adall al-warä', missing a dot. It should be read as 'adhall'. We would like to thank Richard van Leeuwen for solving this matter.

64 BnF, ms Arabe 1907, fol. 3r; BnF, Ms Arabe 1908, fol. 2 r.

65 BnF, ms Arabe 1907, fol. 9r; BnF, Ms Arabe 1908, fol. 4V.

$66 \mathrm{BnF}, \mathrm{MS}$ Arabe 1907, fol. 9v; BnF, Ms Arabe 1908, fol. 5r. See also De la Croix's description of the city of Utrecht's response to Louis XIv's conquests in BnF, Ms Arabe 1907, fol. 15V; BnF, Ms Arabe 1908, fol. 8r.

67 BnF, ms Arabe 1907, fol. 23r; BnF, Ms Arabe 1908, fol. 12r. See Christie, 'The Origins'; Christie, “Curses”'. For some examples of the term used for the Mongols, see Van den Bent, Mongols in Mamluk Eyes, 109, 130, 163, 193. These older texts do not usually contain the addition 'until Judgement Day'. 
his report on the communication between the Duke of Luxemburg and Louis XIV regarding a battle at Woerden that did not go particularly well: laysa al-mukhäțir bi-mahmūd wa-law salaman ('the reckless one is not deserving of praise, even if he is unharmed') and $m \bar{a}$ kull marra taslam al-jarra ('the jar will not remain whole every time'). ${ }^{68}$ The text displays De la Croix's familiarity with Arabic writing traditions and his conviction that in order to sway his audience, he could not take a regular French pamphlet and simply render it into Arabic, but that he needed to work in a format and register recognisable to the Syrian audience he had in mind. These considerations are likewise visible in his use of the fable at the end of the pamphlet.

\section{The Fable of the Sun and the Frogs}

Early modern Europe had developed multiple ways of influencing audiences, targeting publics with a combination of songs, pasquils, medals, poems, celebrations, prints, and pamphlets. The 'image battles' between Louis XIV and his opponents were aimed at national elites and foreign powers. ${ }^{69}$ Hendrik Ziegler discerns various phases in the glorifying representations of Louis XIV. In the early parts of Louis's reign (until the middle of the 1670s), he promoted his image as Sun King and reacted aggressively to people who tried to mock him. Only after the Franco-Dutch war did he give up on the 'tit-for-tat smear campaigns that had been his favourite strategy to counter the deprecating images peddled by his enemies'..$^{\circ}$

While the media varied, the French had invented a strong and consistent theme with which to attack the Dutch in 1672 and 1673 , with Louis as the sun consuming the Dutch. Ambassador Marquis de Nointel was at Chios when he heard the news about the French capture of Maastricht in June 1673. He immediately organised a large celebratory banquet in the courtyard of the local Capuchin convent, with a half-moon table in the middle, surrounded by another twelve tables for less important guests. The arcades of the convent were decorated with garlands, flower wreaths, fruit, and inscriptions in French, Italian, and Greek. The people were treated to a wine fountain and a rock of marzipan and candied fruit. An allegoric firework represented 'a Dutchman consumed by the Sun, for having approached the dominating star too closely'. ${ }^{11}$ This theme also returned in the Arabic translation of a fable that was attached to the pamphlet, that of the Sun and the Frogs. This fable, then, just as the firework at Chios, was a fierce attack on the Dutch. The French annoyance mostly concerned the 'slandering' of Louis's name and the honour of the French.

$68 \mathrm{BnF}, \mathrm{MS}$ Arabe 1907, fol. 21v; BnF, Ms Arabe 1908, fol. $11 \mathrm{r}$.

69 See on the 'multimediality' of influencing audiences for instance Burke, Fabrication; Haks, Vaderland; Claydon and Levillain (eds.), Louis XIV Outside in.

70 Ziegler, 'Image battles', 29.

71 Vandal, Odyssée, 119: A'Hollandais consumé par le soleil, pour avoir approché de trop près l'astre dominateur.' On the fantastic shapes of early modern fireworks, especially those for Louis XIV in Versailles, see Salatino, Incendiary Art, 11-13. 
The genre of the political fable gained an enormous popularity in the second half of the seventeenth century in Western Europe..$^{72}$ In 1672 both Jean Commire S.J. and Jean de la Fontaine published versions of Aesop's old fable. ${ }^{73}$ Commire's adaptation in Neolatin (Sol et Ranae) was a political allegory of Louis's campaign in the Dutch Republic. The Dutch, who are represented by frogs, try to obscure the rays of the sun through the creation of foul vapours, but the sun (Louis XIV) punishes them and dries out the swamp with its rays. ${ }^{74}$ A 1672 French pamphlet, Devise pour le Roy, sur les Préparatifs de la Campagne de l'An 1672, provided its readers with translations from the Latin fable into French, Italian, and Spanish. ${ }^{75}$ Moreover, the author again referred to the supposed Joshua medal, stating playfully that the original pamphlet had been printed in Amsterdam under the sign of Joshua: 'Justa exemplar editum Amstelodami ad Insigne IOSVE'. ${ }^{76}$ The pamphlet was also quickly translated into English and published in the same year: it stressed its translation in 'elegant verse'. ${ }^{77}$ Some of the pamphlets were indeed poetically done, with La Fontaine using the onomatopoeic république aquatique (aquatic republic) as synonym for the Dutch Republic, which sounded like the croaking of frogs. ${ }^{78}$ In the same year, a Dutch translation with an answer to the French insults was published, in which the frogs were represented in a positive way. ${ }^{79}$ We can now also add an Arabic version to this list, aimed explicitly at an audience of 'the Turcs [Muslims] of Syria', although unlike its European counterparts it was set in prose rather than verse.

The beast fable was a known story type in the Arabic-speaking world. Fables have been classed by some medieval authors as khurāfät, emphasising their fictitiousness, but they were also referred to as mathal, a term that can have a variety of meanings, including 'proverb' and 'parable'. The corpus of Arabic beast fables was influenced by the Aesopica, but even more so by Persian stories, both originally Persian and translated from Indian. The collection Kalila wa-Dimna is the most famous example of the latter category, but they were also embedded in all sorts of literary works, from zoological treatises and chronicles to The Thousand and One Nights, to which they were added somewhere between the sixteenth and eighteenth century. Fables served to entertain, but also to instruct and educate, being aimed at members of the court, perhaps even rulers, but also at children. Some preach values of honesty, cooperation, and tolerance; others emphasise the need for good rulership, justice, or loyalty. ${ }^{80}$ The fable of the Sun and the Frogs, then, would not have been a new concept to an educated Arab audience. What does appear to have been new and unusual in the Arabic context is that this fable was used in the context of a very specific political event, in which the characters represent identifiable people.

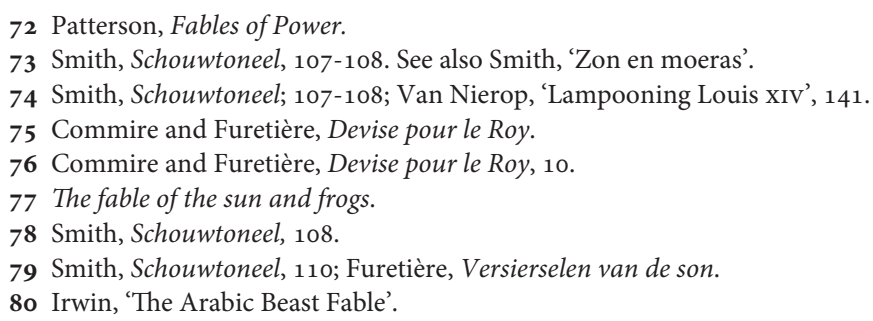


De la Croix clearly considered the fable to be a helpful addition to his narrative, and he may well have been familiar with the Arabic fable tradition through his study of the language and its literature ${ }^{81}$ As in the pamphlet proper, however, he made accommodations for his Aleppo audience, assuming that they might need more information to fully understand all the references and implications in the text (or perhaps wanting to make absolutely sure that the text was not interpreted in a different way). The audiences for the European versions - whether they read the story in Neolatin, French, Italian, Spanish, English, or Dutch - were clearly assumed to be able to interpret the fable's meaning unaided, as none of those texts contain clarifying remarks. For the Arabic, however, De la Croix believed it prudent to include paratextual marginalia designed to direct the reader towards the desired interpretation. Most of his background information was exclusive to the Arabic texts. The French portion of Arabe 1907 lacks these remarks altogether, while the French section of Arabe 1908 has remarks corresponding to those in the Arabic - but they are very terse, hinting at the underlying meaning rather than explaining it, as the Arabic text does. ${ }^{82}$ In the latter, we find twelve separate notes in the margins, with a total word count of more than two-thirds of the fable itself. To illustrate the author's approach, we will discuss the fable and the marginal comments more extensively in the following paragraphs.

The fable opens with the introduction of its main characters. The frogs, having sprung from clay, live in pools. Their strength and power have reached their summit, thanks to the help and care of the sun. In the margins the author explains that the sun represents 'the sultan of France', as the sun is depicted on his banners and flags. The frogs are the 'Flemings' because of the many pools in their country (fig. 3). When the frogs' tyranny became too great, the cows that grazed in the neighbouring meadows and the predatory animals on the shores fled, fearing their intrigues. The frogs' insolence reached the point that they believed they could fearlessly inhabit the Great Ocean (al-bahr al-muhit $)$. They repeatedly battled the porpoises (al-mursawin), and in this manner defeated the tunas (al-tawinn) and the largest of fish. In the margins, the author explains that the porpoises represent the English, because they can be found at the English coasts, and the tuna the Spanish, as tuna are caught around the Spanish isles. These successes led the frogs to arrogance, and they forgot the sun's beneficence towards them. The marginalia here emphasise that it was France that raised the Flemings to their position, and that they are now ungrateful. ${ }^{83}$

Despite the sun being worshipped - the text in the margin points out that the Zoroastrians (majūs) used to worship the sun as an idol - the frogs considered him with tyrannical jealousy and tried to slander him. When the sun drives his chariot to the coasts of India, decides to water his horses in the Ebro, or rises to a high spot on the mountain of lions, the frogs croak and utter false complaints, stating that the sun has destroyed everything. Again, the author used the margins to provide the correct reading for his audience.

81 Sebag, 'Sur deux orientalistes', 90-91.

82 Compare, for instance, the Arabic report on the Joshua medal in BnF, Ms Arabe 1907, fol. $27 \mathrm{r}$ and BnF, Ms Arabe 1908, fol. 13v, to the succinct French '[l]es medailles insolentes des Hollandois' in BnF, Ms Arabe 1908, fol. $18 \mathrm{v}$.

83 BnF, ms Arabe 1907, fols. 24r-25v; BnF, Ms Arabe 1908, fol. $13 \mathrm{r}$. 


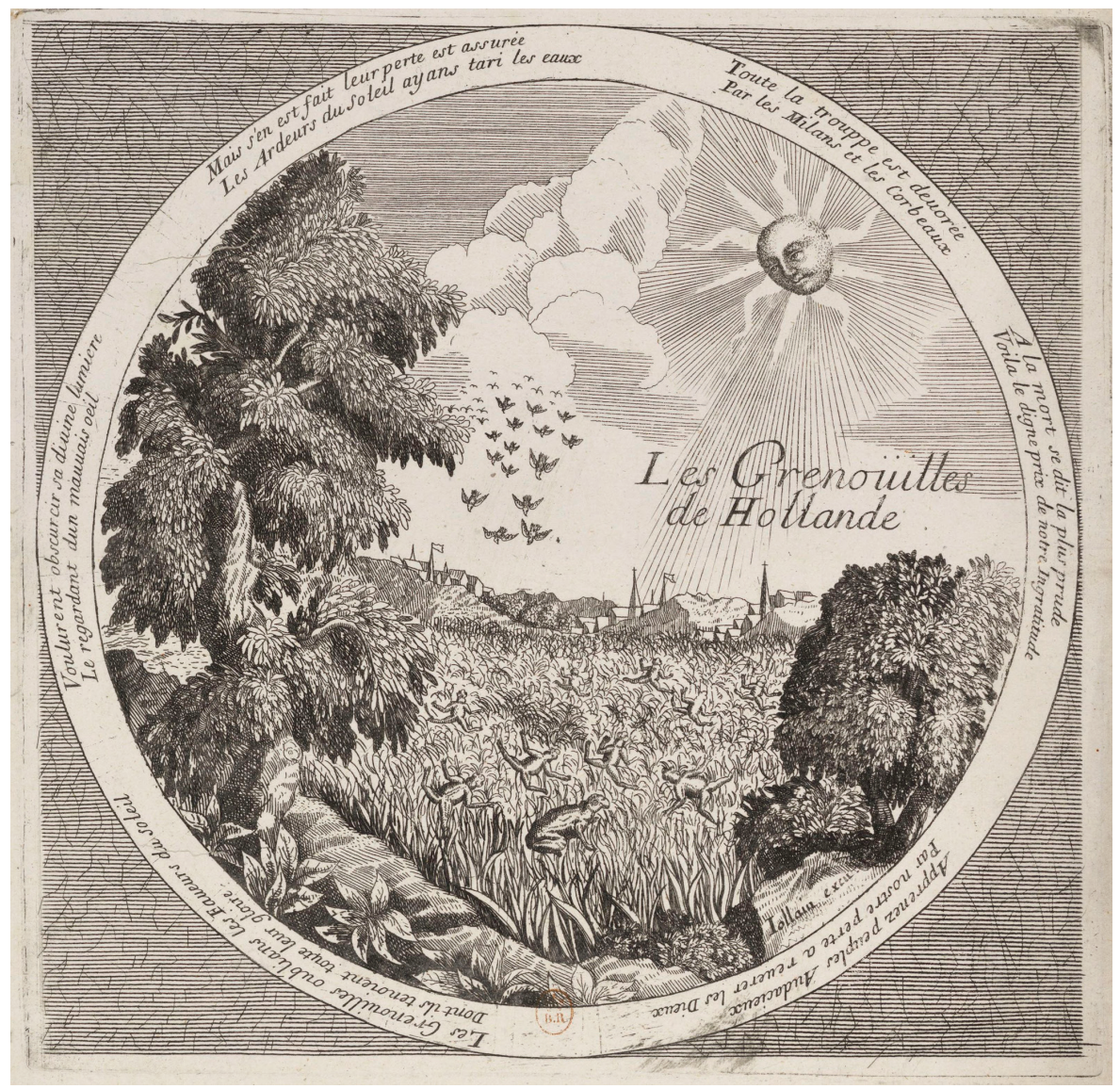

Fig. 3 Jollain, Les Grenouilles de Hollande. Caricature politique, c. 1672, engraving, Paris, Bibliothèque nationale de France.

The Flemings never cease to speak ill of the French in the 'divans' of kings. They slander and malign him. The Flemings made an effort to take over French business in the Indies, and the chariot represents the ships. The Ebro stands for the king of Spain, who has a river called the Ebro - here De la Croix again uses the comparison to the River Jayhūn (Amu Darya). The watering of the horses denotes the attempts of the French to fight the Spanish in the old days, from which the Flemings tried to dissuade them. This might be a reference to the Treaty of Aix-la-Chapelle (1668), in which the Dutch Republic mediated between France and Spain. The rising to the mountain of the lion, the marginalia explain, refers to the journey of the French sultan to Flanders some three years earlier, as the lion adorns the banners and flags of the Flemings (fig. 4) ${ }^{84}$ 


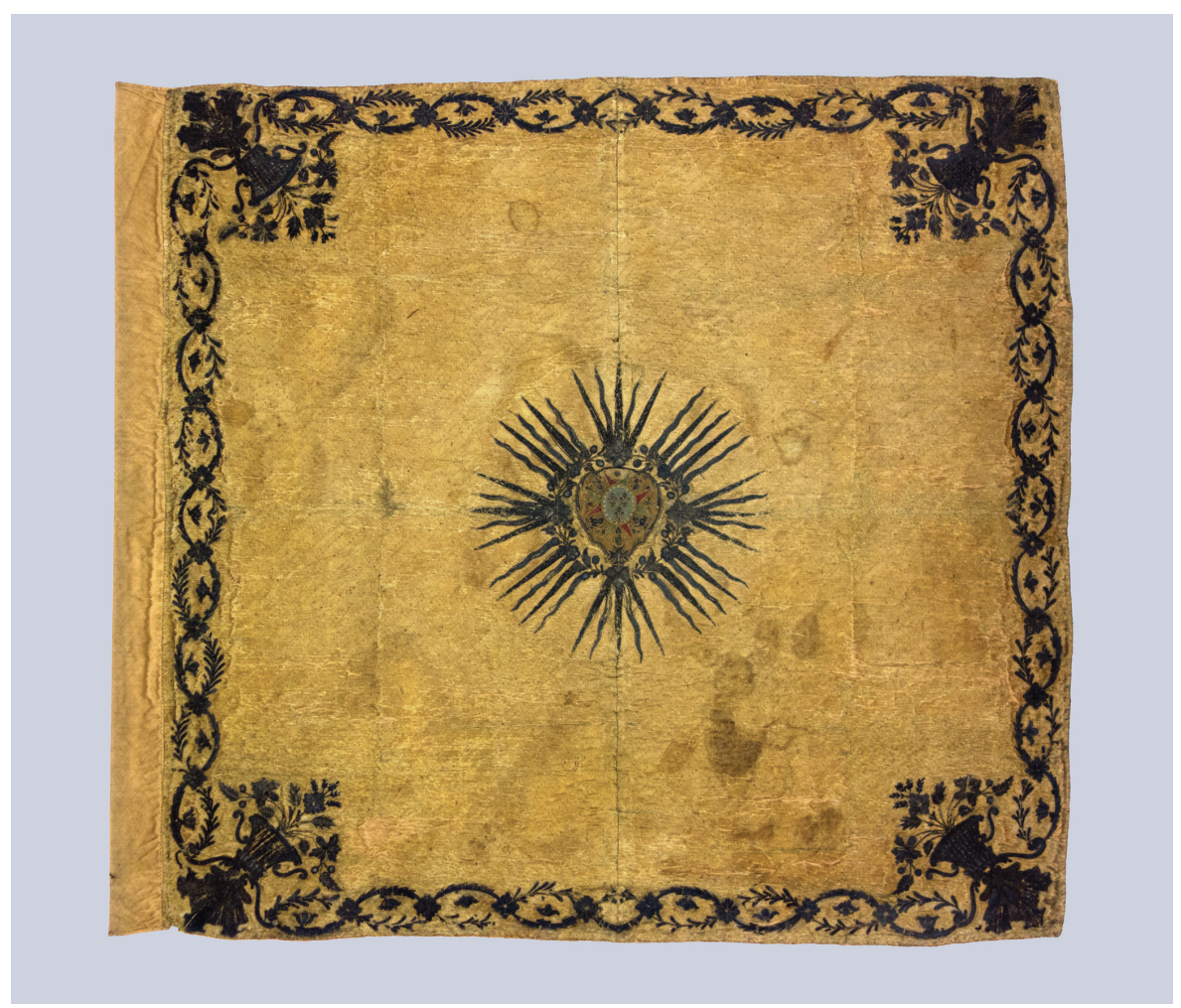

Fig. 4 Banner of Louis XIv, King of France, seventeenth century, silk with silver metallic thread, 96,5 $\times 100,3 \mathrm{~cm}$, New York, Metropolitan Museum of Art.

The frogs also threatened the sun with assault and the sword of their revenge, ordering him to stay in place without moving. Wherever the flaming chariot went in its circuit from east to west, this perfidious group tried to cut it off and block its way. This was again a reference to the existence of a medal of Joshua stopping the sun, which the Dutch had supposedly planned to make in 1669-1670. In the margin, the author explained that the 'Flemings had taken metal medals (qūnät) and made a print like on piastres (qurüsh)'. On these medals, they had depicted the prophet Joshua stopping the sun with a sign, De la Croix continues to explain, with the intention of stopping the sultan of France from his travels throughout the land. The Franco-Dutch 'image-battle' from some years before was thus transferred and explained to a public presumably unfamiliar with the existence of medals: the author had to make a comparison with coins. ${ }^{85}$

In order to stop the sun, the frogs, by stamping their sinister feet, disturbed the mud in their pools, and shook the smelling holes and standing waters, making dark vapours rise that clouded the clear light of the day. The sun laughed at them, saying that 'these 
launched arrows will come down again on your heads' ${ }^{36} \mathrm{He}$ then aimed his rays and the rest of his power at the frogs, turning the black vapours into blazing lightning and hail, thus defeating the wretched frogs with a storm. They attempted to hide in the reeds and clay to escape the disaster that befell them, but both were useless. The marginalia again provide additional information: the sun assembling its rays represents the king of France assembling his troops. The storm stands for the invasion, while the hail is the equivalent of the cannons and muskets. The 'disaster that befell them' refers to the Dutch opening their seawater sluices, flooding their lands, until their cities were taken, their possessions destroyed and the bodies of the soldiers left as food for scavengers and fish. The last bit is clearly the explanation for what follows in the fable: the half-burned frogs, their intestines sticking out of dented bellies, became food for the crows and vultures. It is related, the story concludes, that one frog who was wiser than the rest, said while he lay dying: 'It is appropriate what happened to us. This is the punishment for those who meet good with evil. And you who will succeed us, you must bow down to the sun. ${ }^{87}$

De la Croix thus translated the original, a Neolatin political fable in verse, into a short prose story in Arabic, by which method he imported a European discourse and a European way of influencing audiences to seventeenth-century Syria. But like in the pamphlet proper, the author took pains to tailor it to what he considered to be the needs of his local audience by providing ample explanation. That explanation pertained to the text proper, namely to whom and what do the story's elements represent, but also to its historical context, namely which event caused this specific element to be included. Unfortunately, we do not have the evidence to analyse how De la Croix's intended Syrian audience responded to his pamphlet. Yet it is clear that the French saw benefits in expanding their 'image battle' into the Ottoman Empire, and that they made a conscious attempt to render their propaganda as effective as possible.

\section{Conclusion}

The year 1672 not only saw an actual war on the ground, with Louis xiv's invasion of the Dutch Republic, but also an ideological war that was - at least in part - fought by means of pamphlets. The existence of an intensive exchange of pamphlets and other media between authors in Western Europe has long been known, but the 'Risāla mukhtașara taḥtawī 'alā dhikr al-futūhāt al-muyassara li-l-malik al-a 'ẓam qayșarā Faransā' shows that news and propaganda concerning the Year of Disaster also reached the Ottoman Empire. Not only did the French target the upper echelons of the Sultan's court with their propaganda, but they extended their publicity to an urban readership in major cities, the group at whom this pamphlet was specifically aimed.

In order to target such an audience, the author had to consider how to best reach these potential readers, and how to convince a population with a very different cultural, 
linguistic, and religious background. The Aleppo pamphlet clearly profited from the rise of French orientalist scholarship in the second half of the seventeenth century, as its author enthusiastically employed his knowledge of the Arabic language and traditions. Using Arabic literary conventions combined with wide-ranging explanations of context and background, he employed an existing European discourse - Louis XIV as the 'Sun King', his image of a victorious army commander, and a well-known and popular fable - in a new environment. The concern for Dutch attempts to discredit and slander Louis XIV demonstrates that in the eyes of De la Croix and others involved in the production and distribution of this pamphlet, it mattered deeply how the Arabic-speaking Syrian urban elites saw France. As such, this pamphlet demonstrates an even further integration of the Ottoman Empire in the European media landscape, far beyond its capital city of Istanbul.

\section{Bibliography}

\section{Archival Sources}

Paris, Bibliothèque nationale de France (hereafter BnF), MS Arabe 1907, J.C. [Jean François de la Croix], Relation des victoires de Louis XIV sur les Hollandais, en arabe, suivie de la fable du Soleil et des grenouilles, 1672, [1673].

Paris, BnF, MS Arabe 1908, J.C. [Jean François La Croix the Younger], Relation des victoires de Louis XIV sur les Hollandais, en arabe, suivie de la fable du Soleil et des grenouilles, 1673.

\section{Printed Sources}

Amsler, Nadine, Henrietta Harrison, and Christian Windler, 'Introduction. Eurasian Diplomacies around 1800. Transformation and Persistance', The International History Review 41 (2019/5) 943-946.

Baars, Rosanne M., 'Constantinople Confidential. News and Information in the Diary of Jean-Louis Rigo (c. 1686-1756), Secretary of the Dutch Embassy in Istanbul', Lias 41 (2014/2) 143-171.

Bent, Josephine van den, Mongols in Mamluk Eyes. Representing Ethnic Others in the Medieval Middle East. PhD diss., University of Amsterdam, 2020.

Boitel, Isaure, L'image noire de Louis XIV. Provinces-Unies, Angleterre (1668-1715) (Seyssel 2016).

Boogert, Maurits van den, 'European Patronage in the Ottoman Empire. Anglo-Dutch Conflicts of Interest in Aleppo (1703-1755)', in Alastair Hamilton, Alexander H. de Groot, and Maurits van den Boogert (eds.), Friends and Rivals in the East. Studies in Anglo-Dutch Relations in the Levant from the Seventeenth to the Early Nineteenth Century (Leiden 2000) 187-222.

Brouwer, Judith, Levenstekens. Gekaapte brieven uit het Rampjaar 1672 (Hilversum 2014).

Burke, Peter, The Fabrication of Louis XIV (New Haven and London 1992).

Carra de Vaux, B. and L. Gardet, 'Basmala', in P. Bearman et al. (eds.), Encyclopaedia of Islam, 12 vols. (Leiden 2nd ed. 1960-2005) I, http://dx.doi.org/10.1163/1573-3912_islam_COM_0102 (Accessed 27 August 2020).

Christie, Niall, 'The Origins of Suffixed Invocations of God's Curse on the Franks in Muslim Sources for the Crusades', Arabica 48 (2001) 254-266.

Christie, Niall, “'Curses, Foiled Again!” Further Research on Early Use of the Hadalahum Alläh Invocation during the Crusading Period, Arabica 58 (2011) 561-570.

Claydon, Tony, and Charles-Édouard Levillain (eds.), Louis XIV Outside in. Images of the Sun King beyond France, 1661-1715 (Abingdon 2016).

Commire, Jean, and Antoine Furetière, Devise pour le Roy, sur les Préparatifs de la Campagne de l'An 1672. Expliquée par un sonnet traduit en plusieurs langues, ensemble une Fable Latine traduite en François, sur le mesme sujet (Paris: Charles de Sercy, 1672). 
Do Paço, David, 'A Social History of Trans-Imperial Diplomacy in a Crisis Context. Herbert von Rathkeal's Circles of Belonging in Pera, 1779-1802', The International History Review 41 (2019/5) 981-1002.

Dursteler, Eric R., Venetians in Constantinople. Nation, Identity, and Coexistence in the Early Modern Mediterranean (Baltimore 2006).

Furetière, Antoine, Versierselen van de son en de kick-vorssen en van de kick-vorssen en padden. 't Eene gedicht in Vranckrijck door M. de Furetiere, abt van Chalivoy, en 't andre in Hollant uyt de wolcken gevallen, beyde uyt het Frans vertaelt (s.l., s.d. [1672]).

Ghobrial, John-Paul A., The Whispers of Cities. Information Flows in Istanbul, London, and Paris in the Age of William Trumbull (Oxford 2013).

Haddad Jonathan, 'People before Print. Gens de Lettres, the Ottoman Printing Press, and the Search for Turkish Literature', Mediterranean Studies 25 (2017/2) 189-228.

Haegse Donderdaegse Post-tydinghe, 14 December 1673.

Haks, Donald, Vaderland en vrede, 1672-1713. Publiciteit over de Nederlandse Republiek in oorlog (Hilversum 2013).

Hamilton, Alexander, Alexander H. de Groot, and Maurits van den Boogert (eds.), Friends and Rivals in the East. Studies in Anglo-Dutch Relations in the Levant from the Seventeenth to the Early Nineteenth Century (Leiden 2000).

Harms, Roeland, De uitvinding van de publieke opinie. Pamfletten als massamedia in de zeventiende eeuw. PhD diss., University of Utrecht, 2010.

Harvey, Steven, 'The Author's Introduction as a Key to Understanding Trends in Islamic Philosophy', in Rüdiger Arnzen and Jorn Thielmann (eds.), Words, Texts and Concepts Cruising the Mediterranean Sea. Studies on the Sources, Contents and Influences of Islamic Civilization and Arabic Philosophy and Science (Leuven 2004), 15-32.

Helmers, Helmer J., The Royalist Republic. Literature, Politics, and Religion in the Anglo-Dutch Public Sphere, 1639-1660 (Cambridge 2016).

Helmers, Helmer J., 'Public Diplomacy in Early Modern Europe', Media History 22 (2016/3-4) 401-420.

Hinz, Walther, Islamische Masse und Gewichte. Umgerechnet ins metrische System (Leiden 1955).

Irwin, Robert, 'The Arabic Beast Fable', Journal of the Warburg and Courtauld Institutes 55 (1992) 36-50.

Israel, Jonathan I., The Dutch Republic. Its Rise, Greatness, and Fall, 1477-1806 (Oxford 1998).

Israel, Jonathan I., 'Trade, Politics and Strategy. The Anglo-Dutch Wars in the Levant (1645-1675)', in Alastair Hamilton, Alexander H. de Groot, and Maurits van den Boogert (eds.), Friends and Rivals in the East. Studies in Anglo-Dutch Relations in the Levant from the Seventeenth to the Early Nineteenth Century (Leiden 2000) 11-23.

Israel, 'The Dutch Merchant Colonies in the Mediterranean during the Seventeenth Century', Culture, Theory and Critique 30 (1986/1) 87-108.

Levillain, Charles-Édouard, Vaincre Louis XIV. Angleterre, Hollande, France. Histoire d'une relation triangulaire, 1665-1688 (Seyssel 2010).

Mansel, Philip, King of the World. The Life of Louis XIV (London 2019).

Mansel, Philip, Aleppo. The Rise and Fall of Syria's Great Merchant City (London 2018).

Masters, Bruce, The Origins of Western Economic Dominance in the Middle East. Mercantilism and the Islamic Economy in Aleppo, 1600-1750 (New York and London 1988).

Masters, Bruce, 'The View from the Province. Syrian Chronicles of the Eighteenth Century', Journal of the American Oriental Society 114 (1994/3) 353-362.

Matar, Nabil. I., Europe through Arab Eyes, 1578-1727 (New York 2009).

Matar, Nabil, 'The Protestant Reformation through Arab Eyes, 1517-1698', Renaissance Quarterly 72 $(2019 / 3) 771-815$.

Montoya, Alicia C., 'Zie hier een vreemde oorlog. Constructies van emotie in Madame de Sévignés brieven over de Frans-Nederlandse oorlog (1672-1678)', in Lotte Jensen and Nina Geerdink (eds.), Oorlogsliteratuur in de vroegmoderne tijd. Vorm, identiteit en herinnering (Hilversum 2013) 87-104.

Nierop, Henk F.K. van, The Life of Romeyn De Hooghe 1645-1708. Prints, Pamphlets, and Politics in the Dutch Golden Age (Amsterdam 2018). 
Nierop, Henk F.K. van, 'Lampooning Louis XIV. Romeyn de Hooghe’s Harlequin prints, 1688-89', in Tony Claydon and Charles-Édouard Levillain (eds.), Louis XIV Outside in. Images of the Sun King beyond France, 1661-1715 (Abingdon 2016) 133-153.

Oddens, Joris, Een vorstelijk voorland. Gerard Hinlopen op reis naar Istanbul (1670-1671) (Zutphen 2009).

Olnon, Merlijn, "'A most Agreeable and Pleasant Creature”? Merzifonlu Kara Mustafā Paşa and the Dutch in the Levant (1668-1682)', Oriente modern 83 (2003) 1-28.

Panhuysen, Luc, Rampjaar 1672. Hoe de Republiek aan de ondergang ontsnapte (Amsterdam 2nd ed. 2017).

Patterson, Annabel, Fables of Power. Aesopian Writing and Political History (Durham 1991).

Rafeq, Abdul-Karim, 'Social Groups, Identity and Loyalty, and Historical Writing in Ottoman and PostOttoman Syria, in Dominique Chevallier (ed.), Les Arabes et l'histoire créatrice (Paris 1995) 79-93.

Reinders, Michel, Printed Pandemonium. Popular Print and Politics in the Netherlands, 1650-72 (Leiden 2013).

Rosenthal, F., The Technique and Approach of Muslim Scholarship (Rome 1947).

Rothman, E. Natalie, Brokering Empire. Trans-Imperial Subjects between Venice and Istanbul (Ithaca 2012).

Rothman, E. Natalie, 'Interpreting Dragomans. Boundaries and Crossings in the Early Modern Mediterranean', Comparative Studies in Society and History 51 (2009) 771-800.

Salatino, Kevin, Incendiary Art. The Representation of Fireworks in Early Modern Europe (Los Angeles 1997).

Sebag, Paul, 'Sur deux orientalistes français du XVIIe siècle. F. Petis de la Croix et le sieur de La Croix', Revue de l'Occident Musulman et de la Méditerranée 25 (1978/1) 89-117.

Shafir, Nir, The Road from Damascus. Circulation and the Redefinition of Islam in the Ottoman Empire, 1620-1720. PhD diss., University of California, 2016.

Smith, Paul J., Het schouwtoneel der dieren. Embleemfabels in de Nederlanden (1567-ca. 1670) (Hilversum 2006).

Smith, Paul J., 'Zon en moeras, hanen en kikkers. Nationale beeldvorming in fabel en pamflet omstreeks 1672', in Karl Enenkel, Sjaak Onderdelinden, and Paul J. Smith (eds.), 'Typisch Nederlands'. De Nederlandse identiteit in de letterkunde (Voorthuizen 1999) 73-91.

The Fable of the Sun and Frogs in Elegant Latin verse, Applyed to the Present State of Affairs between the French and Dutch (London: William Gilbert, 1672).

Trivellato, Francesca, 'Renaissance Italy and the Muslim Mediterranean in Recent Historical Work', The Journal of Modern History 82 (2010) 127-155.

Vandal, A., Odyssée d’un ambassadeur. Les voyages du Marquis de Nointel (Paris 1900).

Vivo, Filippo de, 'Microhistories of Long-Distance Information. Space, Movement and Agency in Early Modern News', Past and Present Supplement 14 (2019) 179-214.

Watenpaugh, Heghnar Zeitlian, The Image of an Ottoman City. Imperial Architecture and Urban Experience in Aleppo in the 16th and 17th Centuries (Leiden 2004).

Wilkins Charles L., Forging Urban Solidarities. Ottoman Aleppo, 1640-170o (Leiden 2010).

Ziegler, Hendrik, 'Image Battles Under Louis XIV. Some Reflections', in Tony Claydon and Charles-Édouard Levillain (eds.), Louis XIV Outside in. Images of the Sun King beyond France, 1661-1715 (Abingdon 2016) 25-36. 